い二従高表

あ録れあいあ

印言上吾觉

ているるてる。証

度言語と五椔

佛表示能

學現るとあ

乙 絶 り、蓉

は対七録

なの兄

な真則 七

いは衆則

と智に㲘

い慧に衆

う分如に

平分別畫智

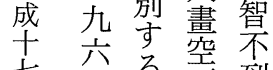

則る空到

㙞こ筆處

則は即切

著で錯忌

語き气䆃

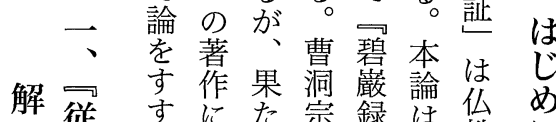

従すにた宗録は伀

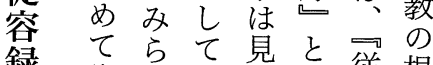

録孔

に

にな従著

たるの悟比容本

といのよ道較録問

の○でうをを題

碧市な強通にで

賑 万顕調し捛あ

録う著せてける

か著ぜ若ると

に 今違、臨の証時

お回が済考悟に

け は司察悟禅

る証証容強妿气禅

は

の に録調え理心

共 焦方る す解問

通点碧とのに題

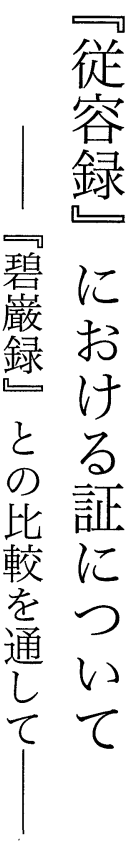

と示戒超撤凡 (2)う能ととのなす悟出 い衆め越開聖言にに文境々るる出

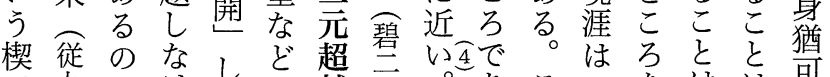
で九でけたの越宍。あこ度はは可 取六あれた山世公まっの縮こ難ま易 り下るばこ两鱼步さてょ郤満しだ

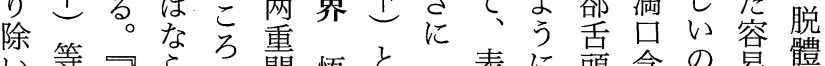
い寺蓯らで関悟と口表に頭含の易

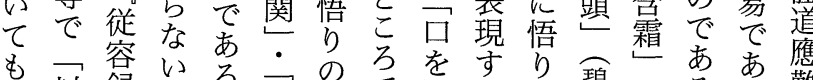
、以録いる。两妙で開るす碧菂る。る矱

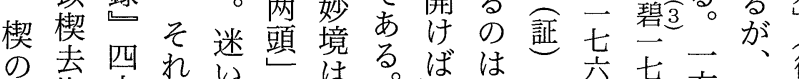

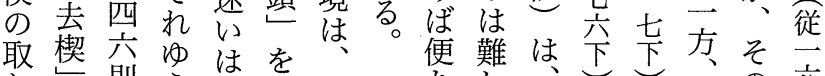

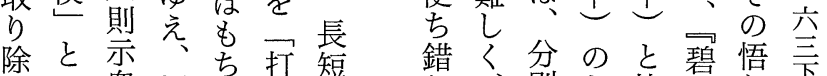

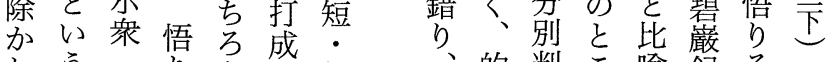

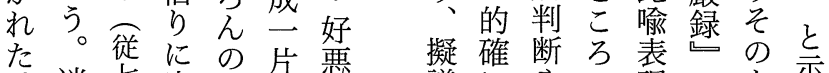

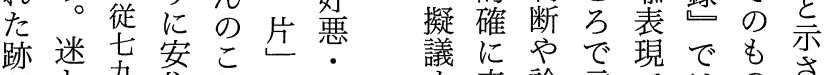
がと䧱とし能㧝表論言ではのさ 残い上寺、、能机守議葉語表をれ うう・る悟射・ばのをにり、現言る て楔五こり射迷即は超つ、歪語う まを悟則をを透悟方不美奇たる悟可表う 


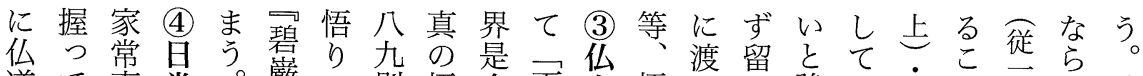

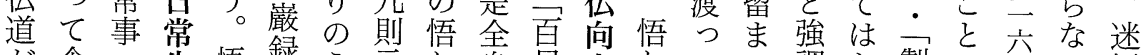

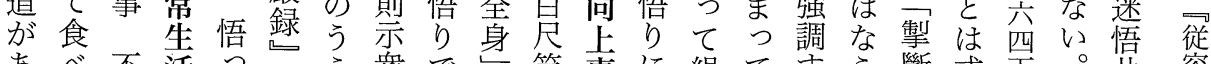

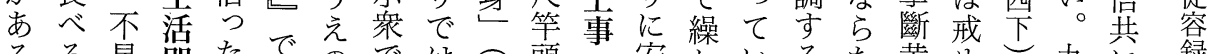
るる是即たでのでは従頭安りいるな黄め更め綵録 わな飽佁とも、修はな従坐徉返てのい金らと六妄

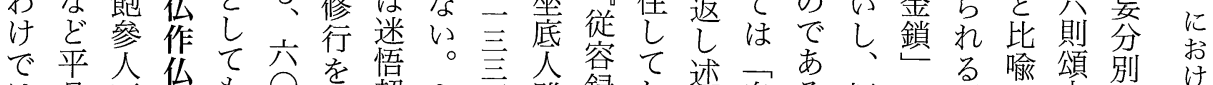

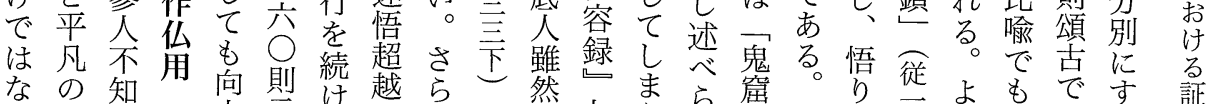

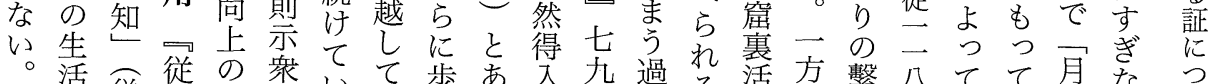

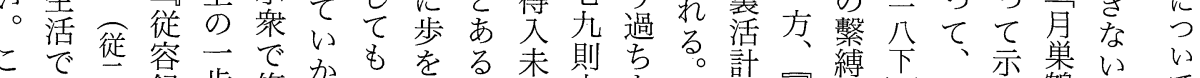

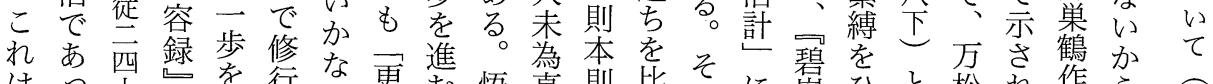

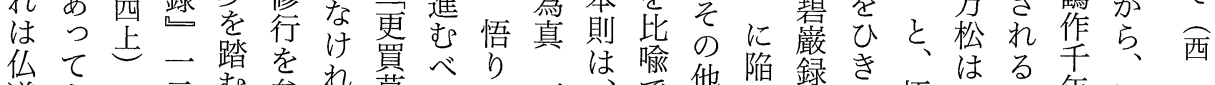

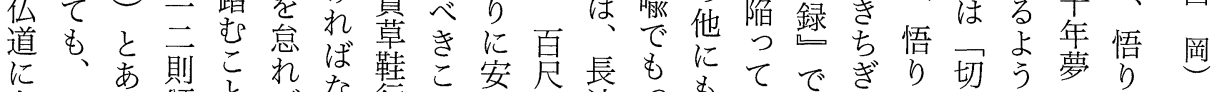
じの。古を元な脚を頭暴て表ま悟な境墨に雪も

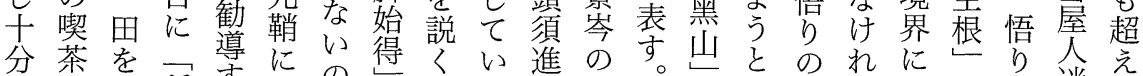

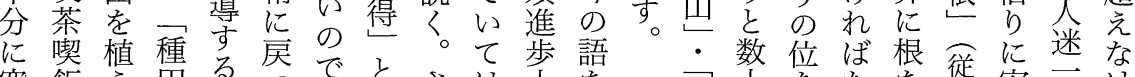

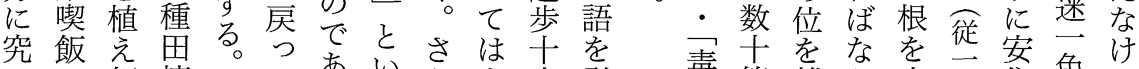

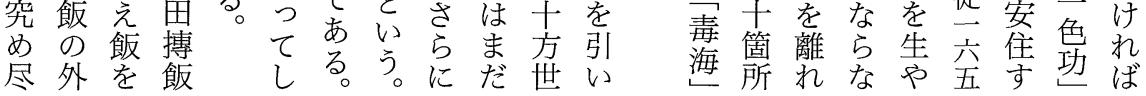

あ生 明 (6)二しさた示界仏の らの觸自四かららに不身ま破方横兰生に則非居乙 わ機處由㫐しにき藏でま塵世徧世活、垂妙士た れ根露自上、は無亦仏出界十干乞悟示用の人 てに堂在こそ固古相遠りで經に方方のりで神語に

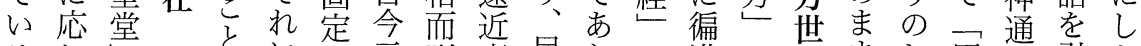
るじ司ににさ至形齊尽り、定満従界ま把田通引加

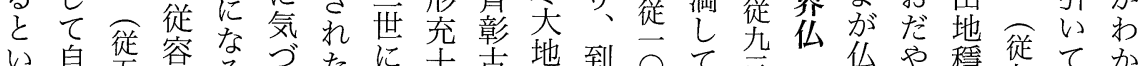

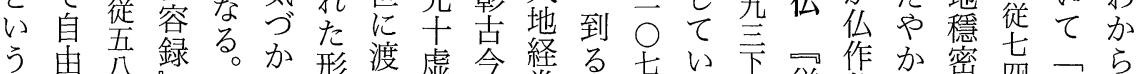

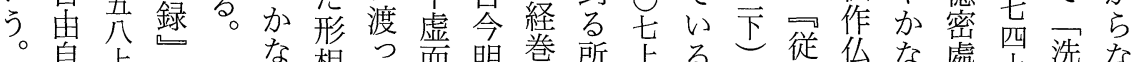
息上三相て而明巻所上る。従允な處些洗な

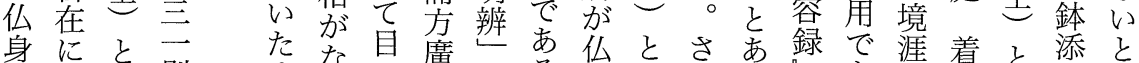

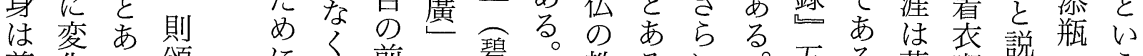
尊化る頌 厳しょ古 が、うに あ尽に一 す干隨 べ世の主 て謖は尺 をどた二 脱こら丈 落にき六

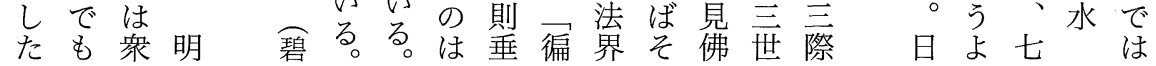

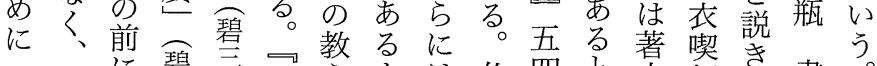

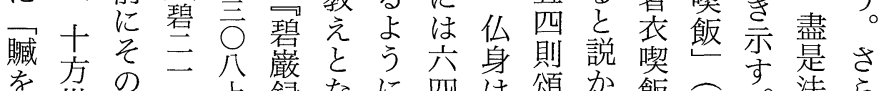

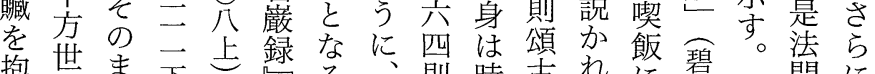

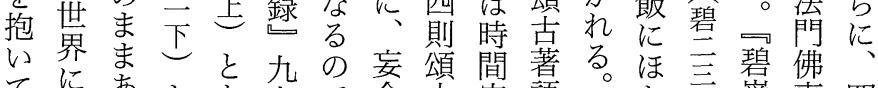

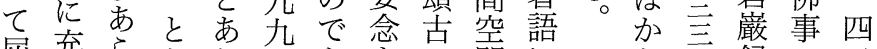

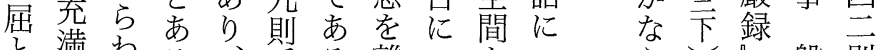

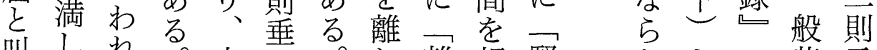
叫て热。六系。犰離超臨なとで柴示

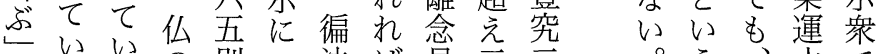

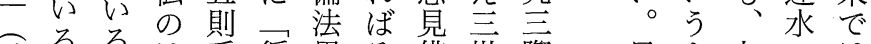


(1) る倮珀正るの凌刃うるて生世待中境地たよ

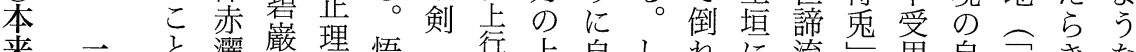

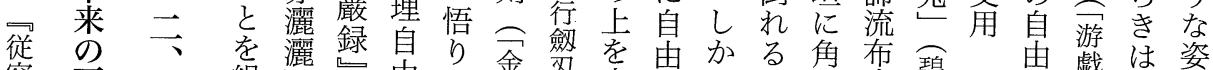

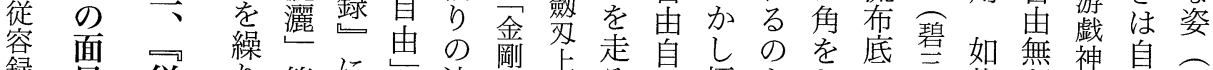

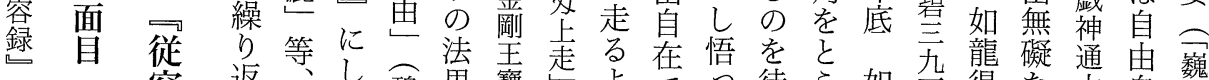
に容返穴碧界寶走よでつ待ら如尔得な大自巍

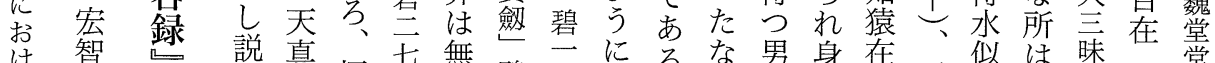
け智し説真悟古無碧五にるな男身在三似は昧っ堂

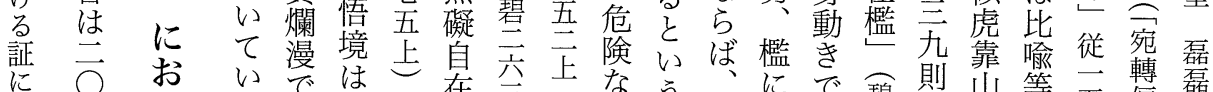

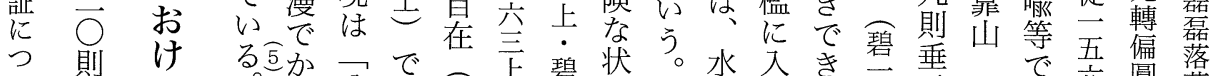

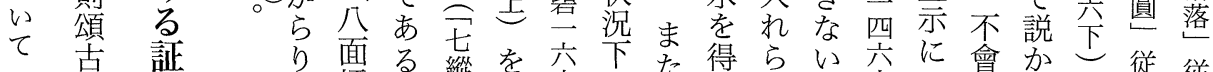
々檽る。縱を公下゙得らい六に會か心従従

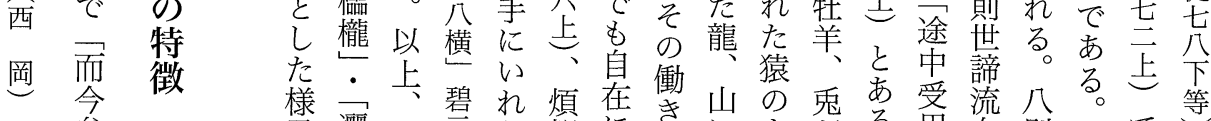

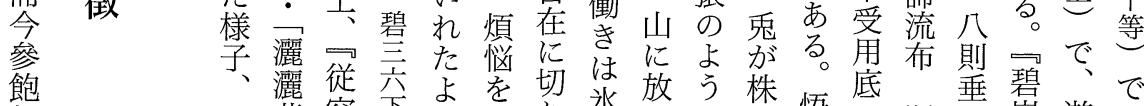

似

當

時 は落容市る粉り水放う株悟底垂撮てで た落録等う粉抜のたにに悟瓶示嚴游あ

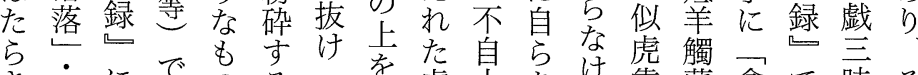
き六にでのる劣虎宙市㸆潘會で昧そ

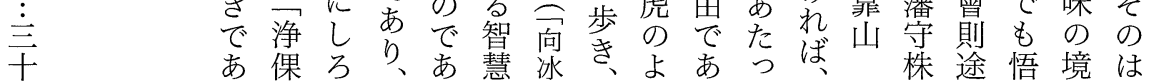

くず田 (3)下万住出笠 (2) のでつ下済きののに. 同し年

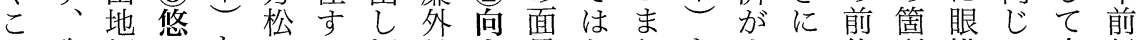
と臨優多ともる悟轉上自なりと大抎後所横で今行 が機游と説五こり身易にく転表愚いにを鼻あに脚 強応信しく六との難く気前迷すのて㧫而るな事 調変歩たこ則な境占づか開。も昔い吾、。る分 さ・移世と本く界危下いら悟こととて猶一本と明 れ自界か則、に徒難たのしのでは眼昔雙来昔辜

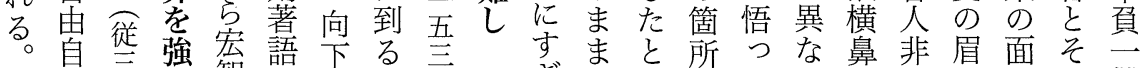
悠在分調智でにの㕵八ぎでしのたる直昔は貝つ雙

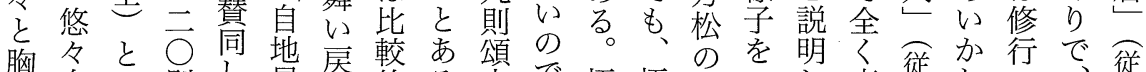

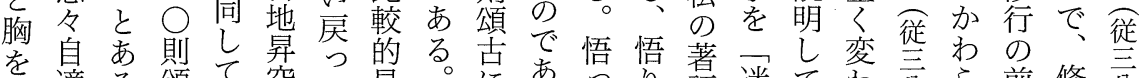

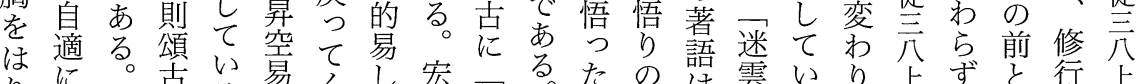

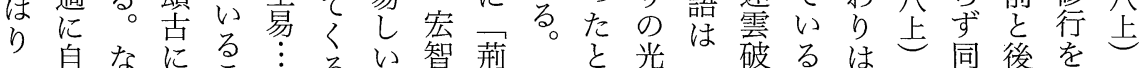

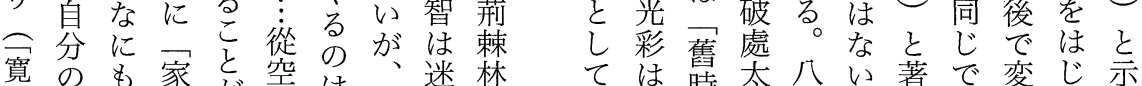

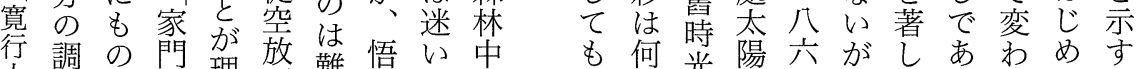
大調に豐理㫌難悟い中方何光陽六がしあわめす

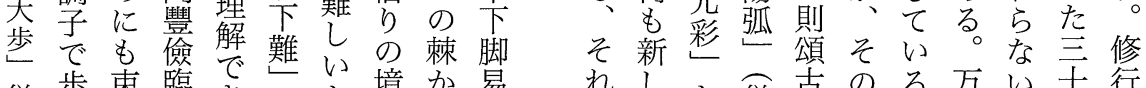
従歩束臨き公と境加易れし飞従古のる万い干行

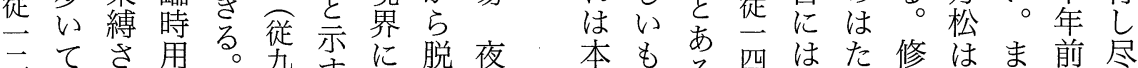

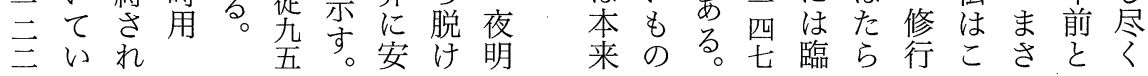


面大のとしがな明

目し前をて真違 5 以

にたと説、市いか上

気隔後々そ悟はに三

づたのとの境認な書

くり境こ境でめつの

こは地ろ地あらた比

そなにははりれ。較

がい二同な、な説検

大説応じに日い示討

切説のでも常。にに

でこ違あの生迷およ

あとを。它染てり

り、で認異束の三基司

あめな縛ま元基従

悟るるる㘘ま対的容

り。ののれが立に録

に起にはず仏をはゅ

縛蓉対 自作乗 のの

ら録し、琚由仏り碧口

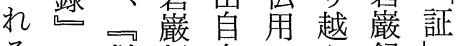

るは従録在で党録し

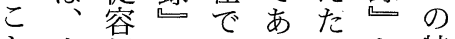

と本録はあるとと特

な来修る。こ大徵

くのは行こそろきが
端釈一そ箇と (4) 容題あ上 坐は則の所市䓡録名り、徥 小のなはまでる。坐心の従

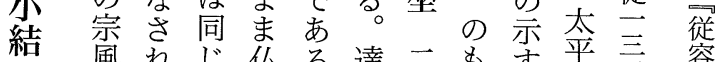

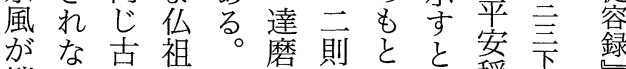
端い則の煩が頌め打穏止 的。を正脳少古るりな拀 に後扱正滅林に所、る昆摬掌 示につい却寺宁化境常る さ曹て教しに苓あつ地生証

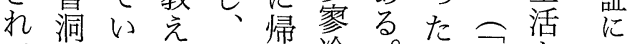

て宗るを壁っ冷。り家をつ

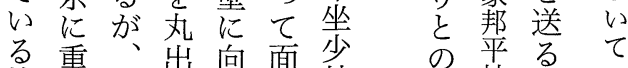
籒重周出向面省林ん帖こ西 所じ知にい壁缺び牢 でらのす默年默り從が岡 あれごる黙し黙し二そ るるとと望た全た公の よくw夎と提境下ま うこう䄋こ齿地ま にの。专ろ令こな仏

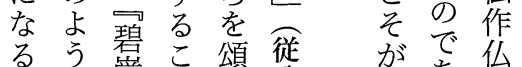

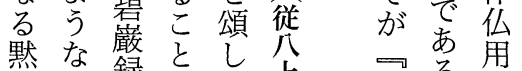

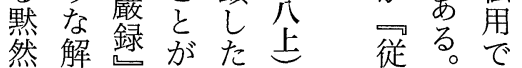

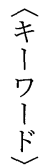

踓

録

稺

㫎

評

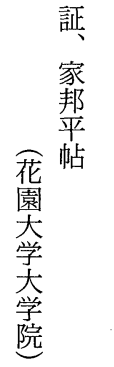

一り解氏思末孷四年 1

○真脱は想玟録季の司 理等禅后美悉社略嚄

七駒兵挍種云録

頁澤通て号禅電 鈔 $^{2}$ 需

参大概説一言学年至連

照学念机語禅修山 仏有了税九修峚 紙政有る○思文九道交 学乙辛四想华則禅頭 研い的年省研解語注 研るな四表究所説録本 紀要指自貪う一三訳こ 要摘由貝方九全禅

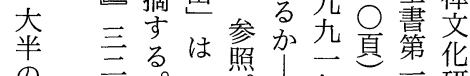

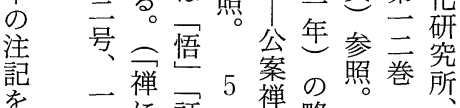
割九証原分略。従一

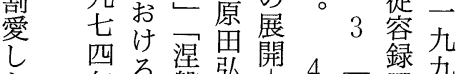

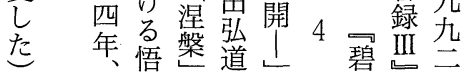

研本詳にめで仏悠 究則細 $\neg$ 市祖々 課にな従王る正自 題立検容䧺。伝適

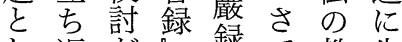
し返㤎録て教生 たう欠にに今え いて如おに回でて のしけおの市い 考てるけ論るく 察い宏る考ここ なる智雪でとと ど。璸はがが 残さ方究明強 さら松圆書確調 れに公悟のにさ たは思の全示れ 課評想考体さる 題唱的えにれ は部相方渡るそ 多分違のつのし い精に違てがて が精つい比大默 、查い、較き然 今なてなしな端 後検ならた特坐

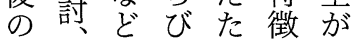




\section{Trends of Practice among Disciples of Nanyue Huisi According to the Xu Gaoseng zhuan}

Akinori Mutō

I have researched disciples who were guided by Nanyue Huisi (南岳慧思), Tiantai Zhiyi (天台智顗) and various teachers of Tiantai, and those who practised Chan meditation in Mt. Tiantai (天台山) referring to the Tiantai Zhizhe Daishi biezhuan 『智者大師別伝』 and the Guoqing bailu 『国清百録』 as supporting materials.

As a result, it was possible to confirm 41 disciples including not only priests but also laymen by means of searching "changuan 禅観(sitting in meditation)", and "chanfa 懺法 (method of repentance)" recorded in the $X u$ Gaoseng zhuan (『唐高僧伝』).

In this thesis, I have focused on such disciples as Huicui (慧璀), Huicheng (惠成), Huiming (慧命), Zhiyi (智顗), Huiyao (慧耀), Huichao (慧超) and Huisi (慧思), and tried to examine the trends in which Buddhist ascetics led and trained by Nanyue Huisi practised Chan meditation, based on the $X u$ gaoseng zhuan.

In a concrete form, I have tried to examine what kinds of training methods were practised by disciples belonging to the Huisi group, and in which regions in China they existed, in accordance with philological methods.

\section{9. "Enlightenment" in the Congrong $l u$ in Comparison with the Biyan lu}

Shūji NisHiOKA

Enlightenment is a fundamental issue in Buddhism, and it is the central concern of Zen as well. This study examines the understanding of enlightenment in the Congrong lu in comparison with the Biyan lu, with some observations made. In regard to the stages of training and the fruits thereof, the Congrong $l u$ does not recognize any significant differences, but the Biyan $l u$ accepts a tentative difference. Therefore, it is important to realize the essence of humanity (the "original face") in the Congrong $l u$, and a major fea- 
ture of that work is its emphasis on living freely without attachment to the concept of enlightenment.

\section{A "12 Division of Time" in Chan - Dunhuang document Pelliot chinois \#3604}

Szu-wei LU

This document is based on the division of time named "the twelve horary signs," and elaborated in the twelve kinds of verses. The unknown author of this document states his thought and practices of Chan through these verses. This was formed under the influence of the Northern Chan School before the eighth century, characterized by Nembutsu (Buddha-Contemplation)-Chan syncretism.

\section{The Problem of An Account of the Coming East of Huineng's Dingxiang Young-sik JEONG}

In this article, I have examined a Korean text An Account of the Coming East of Huineng's Dingxiang written by a Korean monk Kakhun (覚訓). It tells the story that a Silla monk Kim Deabi (金大悲) tried to cut the head off the corpse of Huineng, an episode mentioned in the Jingde Chuandenglu (1004). However, this document is based on two materials: the Sanggaesa jingamsŏnsa daegong tappi 双渓寺真鑑禅師大空塔碑 and the Samguk yusa 三国遺事. Two problems are focused on here. First, a 'Dingxiang' portrait of a Chan master is equivalent to a 'head'; second, the creation of the monk Kim Deabi 金大悲 just originated from a sentence that "there is a statue of Taebi 大悲 in Paengnyul (栢栗) Temple”.

\section{The Kettō Jushuin Gimonshō (決答授手印疑問抄) of Ryōchu (良忠)}

Kōjun HAYASHIDA

This paper is a study about the reason why Ryōchu (良忠) wrote the Kettō 